\title{
Effect of the ground-water regime and nitrogen fertilizer on the yield and quality of apples
}

\author{
J. Visser (IJsselmeerpolders Development Authority, P.O. Box 600, 8200 AP \\ Lelystad, Netherlands)
}

Received 12 March 1985; accepted 23 April 1985

\begin{abstract}
Results are given of a 12-year experiment with Cox's Orange Pippin and Golden Delicious apples on M9 rootstock. A 5-ha field on calcareous clay soil recently reclaimed from the sea was laid out to give two replicates of each of eleven drainage/subirrigation regimes. Three levels of nitrogen treatment were superimposed on this. Results are given of soil physical changes (structure, subsidence and compaction), of root and shoot growth of the trees, and of yield and quality of the fruit.

Key-words: ground-water level, experimental field, calcareous clay soil, soil ripening, subsidence, soil structure, nitrogen mineralization, apple tree, root system, apple production, fruit quality, bitter-pit, standards, norms, nitrogen fertilization, drainage.
\end{abstract}

The experimental field. In 1964 a 5-ha ground-water level experimental field was set up on a calcareous clay soil in the polder Eastern Flevoland aimed at obtaining drainage standards for fruit growing. The lay-out of the ground-water experimental field was based on water-tables of $40,70,100$ and $130 \mathrm{~cm}$ below surface. According to Dutch seasonal ground-water fluctuations, ground-water regimes were also included with a higher water-table during winter than during summer. In total there were 11 ground-water regimes in duplicate (Fig. 1). The ground-water regimes were achieved by subsurface irrigation. All drains were spaced at $4 \mathrm{~m}$.

Within each ground-water regime a nitrogen series was set up in order to distinguish the direct influence of the ground-water regime on the trees from indirect influences via the nitrogen balance. This nitrogen series consisted of an unfertilized plot $(0 \mathrm{~N})$, a normal fertilized plot $(1 \mathrm{~N})$ and a plot fertilized twice as much as the normal plot $(2 \mathrm{~N})$. Through the years $1 \mathrm{~N}$ varied from $75 \mathrm{~kg}$ to $150 \mathrm{~kg} \mathrm{~N} \mathrm{ha}^{-1}$ year $^{-1}$ and consequently $2 \mathrm{~N}$ from 150 to $300 \mathrm{~kg} \mathrm{~N}$ ha $^{-1}$ year $^{-1}$.

Each ground-water regime comprised two varieties of apples: Cox's Orange Pippin and Golden Delicious, both grafted on rootstock M9. The trees were planted at $4 \mathrm{~m}$ distance between the rows and at $2.5 \mathrm{~m}$ in the row. Between the rows was a $2 \mathrm{~m}$ wide grass strip, under the trees a $2 \mathrm{~m}$ wide mulch strip.

Results. After drainage the soil dries and forms cracks: moreover chemical changes take place, caused by the entry of oxygen. The whole complex of processes is known as ripening (Rijniersce, 1983). Regarding soil ripening the following results were obtained. 


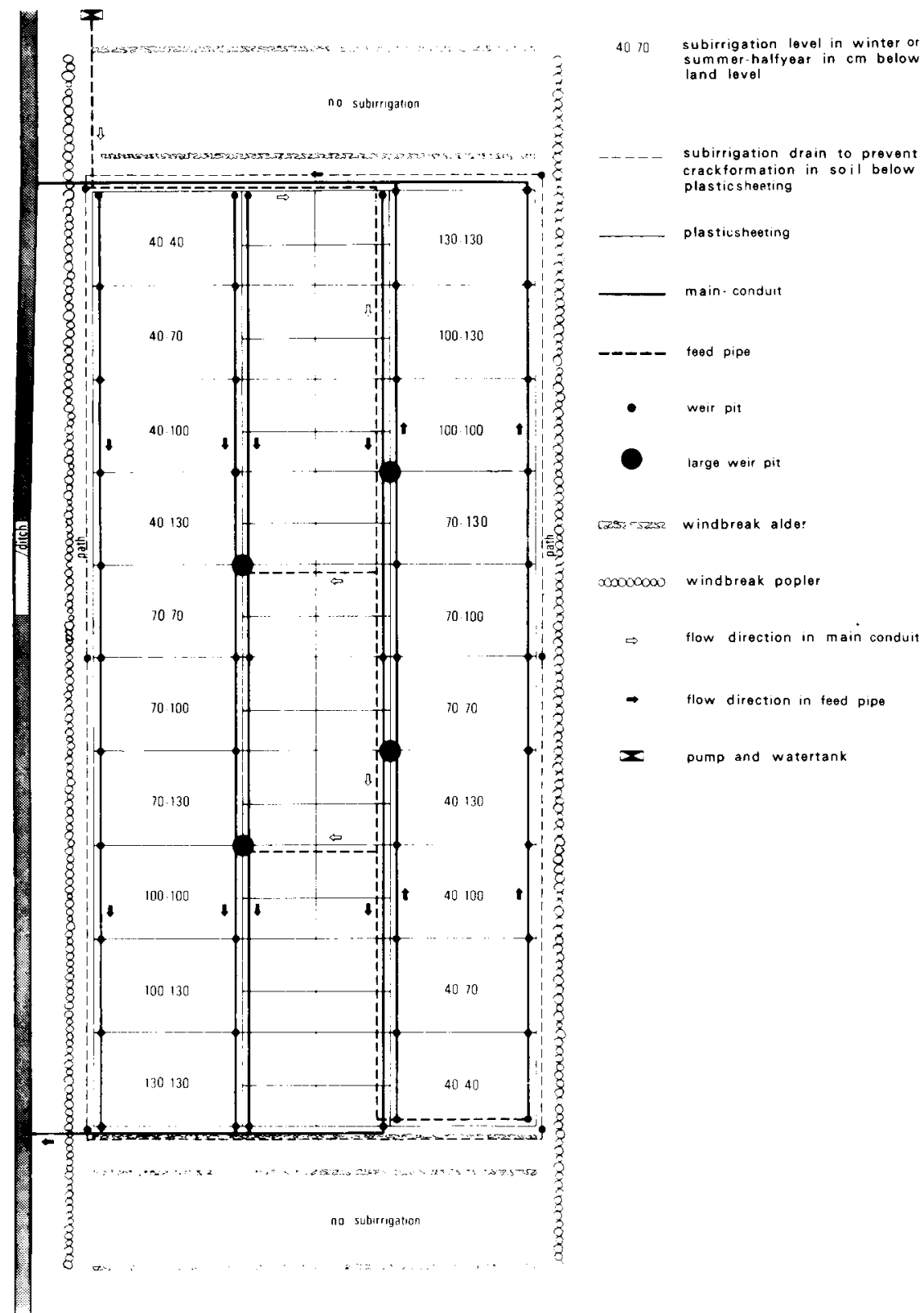

Fig. 1. Plan of the ground-water level experimental fields for fruit growing.

- The degree of subsidence of the soil on the experimental field over the period 1964-1976 was directly proportional to the depth of the summer water-table. The rise in the winter water-table had only a slight effect. 
- The process of crack formation accelerated with increasing depth of the summer water-table. In this soil type cracks remained unchanged even if they were back below the ground-water level for ten years.

- The structure of the top soil was only influenced by the depth of the ground-water when soil was compacted by wheels or feet.

The various ground water regimes in the experimental field affect both the extent and operation of the root system of grasses and trees and the natural fertility of the soil. They influence the natural fertility by the formation of anorganic nitrogen from organic nitrogen (nitrogen mineralization). The nitrogen mineralization was studied by periodically cutting the grass and determining the amount of nitrogen in it. The effect of the water-table in winter over five years was restricted. A summer water-table of $130 \mathrm{~cm}$ gave a maximum mineralization.

At shallow water-tables root density of the apple trees increased in the topsoil under the mulch strip. Under the grass strip, which was also access strip, the soil was compacted and there was not such an effect. The root system as a whole had a greater uptake capacity at deeper water-tables.

At the deepest ground-water regimes available moisture was sufficient, but the apple tree had to form stronger water potentials for water uptake. This gave a reduction in growth. Maximum growth occurred at subirrigation levels of 70 to $130 \mathrm{~cm}$ below surface in combination with a sufficient nitrogen supply. Nitrogen influenced strongly vegetative growth between $0 \mathrm{~N}$ and $1 \mathrm{~N}$. The differences in growth of the trees between $1 \mathrm{~N}$ and $2 \mathrm{~N}$ were mostly slight. The sensibility for periodically high ground-water levels, however, increased at higher nitrogen levels. This was noted on an object with a high ground-water level during winter and a deep ground-water level during summer. Here vegetative growth was $28 \%$ lower at $2 \mathrm{~N}$ than at $1 \mathrm{~N}$.

The production reacted less than the vegetative growth on the treatments. On the fertilized plots the differences in yield of apples due to ground water influences were $10 \%$ at most. The yield tended to be highest at the deepest ground-water levels. There was an adverse influence of nitrogen on all aspects of the quality of the fruit. Differences in the external quality such as skin colour and russeting could almost completely be explained by nitrogen. Only in the size of the Cox's apples there was a slight influence of the ground-water regime, almost similar to the response in vegetative growth.

Bitter-pit attack in the apples was one of the most important storage diseases. In both varieties bitter-pit increased with nitrogen supply. In some years, effects of the ground-water on the quality of the fruit were detected in the occurrence of bitterpit. Bitter-pit attack was stimulated at high water-tables in winter in combination with low summer water-tables. Bitter-pit attack also increased at the summer water-tables of $70-130 \mathrm{~cm}$ with a sufficient nitrogen supply. On these objects vegetative growth was also at a maximum.

Norms for nitrogen fertilization. The amount of first-class fruit of Cox's Orange Pippin and Golden Delicious remained virtually unchanged above average levels of nitrogen in the leaves of 2.2 to $2.3 \%$ and 2.1 to $2.2 \%$ respectively. Above these levels the amount of second-class fruit increased, but the production of such fruit is not 
economic. Therefore, the nitrogen percentages mentioned above also indicate the economic level for nitrogen fertilization. The effects of nitrogen on fruit quality of Golden Delicious were confirmed by Williams \& Billingsley (1974) in the United States.

Norms for drainage. The results obtained did not conclude to one general norm for ground-water standards for fruit growing. In fact this standard will depend on the weight one gives to the different aspects. For the Dutch polders the following norms are taken into account.

- In heavy IJsselmeer polder soils the summer water-table must be able to fall to at least $1.80 \mathrm{~m}$ below the surface to allow formation of adequate soil structure and rooting $(1 \mathrm{~m})$.

- To maintain a rooting depth of $1 \mathrm{~m}$ a minimum drainage depth of $1.10 \mathrm{~m}$ is required.

- The distance between the drains must be such that at drainage rates of 10,5 and 1 $\mathrm{mm}$ per day, the water-table is not shallower than 60,70 and $95 \mathrm{~cm}$ below the surface, respectively.

These requirements result in a rather deep ground-water regime, in agreement with the results of ground-water level experimental fields with arable crops (van Hoorn, 1958), and vegetables (Feddes, 1971). Nitrogen economy, soil structure and soil compaction by feet and machines are the main factors involved.

For fruit growing, however, there is an additional factor. The production increases when vegetative growth is kept within bounds. This is the case when the actual evaporation $\left(E_{\mathrm{a}}\right)$ is somewhat restricted and thus remains smaller than the potential evaporation $\left(E_{\mathrm{p}}\right)$, so $E_{\mathrm{a}} / E_{\mathrm{p}}<1$. In the situation of the Dutch new polders this favours a deep ground-water regime too.

\section{References}

Feddes, R. A., 1971. Water, heat and crop growth. Thesis, Agricultural University, Wageningen.

Hoorn, J. W. van, 1958. Results of a ground water level experimental field with arable crops on clay soil. Netherlands Journal of Agricultural Science 6: 1-10.

Rijniersce, K., 1983. A simulation model for physical soil ripening in the IJsselmeerpolders. Thesis, Agricultural University, Wageningen, and Flevobericht 203, Rijksdienst voor de IJsselmeerpolders, Lelystad.

Williams, M. W. \& H. D. Billingsley, 1974. Effect of nitrogen fertilizer on yield, size and colour of Golden Delicious apple. Journal of the American Society of Horticultural Science 99-2: 144-145.

This synopsis is based on a report, Rijksdienst voor de IJsselmeerpolders, Lelystad, 1983. 266 pp., 94 figs., 145 tables, 112 refs. English.

Available as paper copy (order R038P, $f 69$ including postage) or microfiches (order R038M, $f 22.50$ including postage) at: NARD, clo Pudoc, P.O. Box 4, 6700 AA Wageningen, Netherlands (telex 45015 blhwg $\mathrm{nl}$ ). 